\title{
Penyelesaian Sengketa Hak Milik atas Tanah dalam Perkawinan Campuran di Indonesia
}

\author{
Yoga Nasa Prastyawan \\ Prodi Ilmu Hukum, Fakultas Hukum, Universitas Muhammadiyah Surabaya, Indonesia \\ *Korespondensi : yoga.nasa.2015@law.umy.ac.id
}

\section{Info Artikel}

Diajukan: 05-02-2021

Direview: 08-03-2021

Direvisi: 07-06-2021

Diterima: 09-06-2021

DOI: $10.18196 / \mathrm{mls.v2i4.12813}$

Abstrak
Hukum Agaria di Indonesia menganut asas nasionalisme yang
menyebabkan warga negasa asing tidak dapat mempunyai tanah
dengan status Hak Milik, bahkan bagi warga negara Indonesia
yang menikah dengan warga negara asing tanpa memiliki
perjanjian pisah harta juga tidak diperbolehkan memiliki tanah
dengan status Hak Milik karena dalam hukum pernikahan di
Indonesia mengatur percampuran harta. Lahirnya Putusan
Mahkamah Konstitusi Nomor 69/PUU/XII/2015 berdampak besar dalam esensi pembuatan perjanjian pisah harta, yang menyebabkan perjanjian pisah harta dapat dilakukan setelah pernikahan dilaksanakan. Namun sebelum lahir Putusan Mahkamah Konstitusi tersebut sudah ada Penetapan Pengadilan tentang perjanjian pisah harta. Salah satu contoh Penetapan Pengadilan tentang pisah harta ini adalah Pengadilan Negeri Bekasi, yakni Penetapan Nomor 67/PDT.P/2014/PN.Bks. Pelitian ini secara objektif bertujuan untuk menemukan dasar hukum pembuatan penetapan pisah harta pada perkawinan campuran tanpa perjanjian kawin di Indonesia dan untuk mengetahui penyelesaian sengketa hak milik atas tanah pada perkawinan campuran tanpa perjanjian kawin di Indonesia. Jenis penelitian ini adalah penelitian hukum normatif, dengan bahan penelitian berupa bahan primer, bahan sekunder, dan bahan tersier. Teknik pengumpulan data berupa studi pustaka dan data pendukung diperoleh dengan melakukan wawancara kepada Ibu Pujiastuti, S.H, selaku Notaris. Teknik analisis data secara deskriptif dengan cara pengolahan data menggabungkan data primer, data sekunder, dan data tersier. Hasil penelitian secara deskriptif yang pertama menunjukkan bahwa Dasar hukum pengajuan permohonan pisah harta pada perkawinan campuran dapat menggunakan ketentuan Pasal 186 KUHPerdata. Putusan Mahkamah Konstitusional Nomor 69/PUU/XIII/2015 dan yurisprudensi dari Penetapan Pengadilan Negeri Bekasi Nomor 67/PDT.P/2014/PN.Bks. Hasil penelitian yang kedua penyelesaian sengketa hak milik atas tanah pada perkawinan campuran tanpa perjanjian kawin di indonesia dengan mengajukan permohonan pisah harta oleh salah satu pasangan suami-isteri ke pengadilan sesuai kopetensi relatifnya. Penyelesaian ini menurut peneliti adalah satu-satunya cara yang terbaik dan legal dimata Hukum.

Kata Kunci : penetapan pengadilan negeri, perjanjian pisah harta, perkawinan campuran,

\section{Pendahuluan}

Hubungan dalam ikatan perkawinan adalah hubungan yang sakral tak hanya sebatas hubungan perdata saja melainkan hubungan yang dilaksanakan berdasarkan perintah Tuhan Yang Maha Esa sehingga segala sesuatunya tentu akan dipertanggung 
jawabkan baik di dunia maupun di akhirat. ${ }^{1}$ Perkawinan bukan hanya mempunyai dampak terhadap diri pribadi suami dan istri maupun hubungan antar keluarga suami dengan keluarga isteri,tidak hanya masalah tanggung jawab suami atau isteri tetapi juga mempunyai akibat hokum atas harta yang terbentuk/diperoleh sepanjang perkawinan ,artinya perkawinan juga mempunyai akibat yang bersifat hokum kekayaan keluarga. ${ }^{2}$ Perbuatan hukum perkawinan pasti menimbulkan akibat-akibat hukum yang panjang, dan semua itu diatur oleh penguasa dalam rangkaian Pasal Undang-Undang Perkawinan. Antara lain akibat hukum suatu perkawinan bagi diri pribadi, para pelakunya pihak pria akan menduduki posisi sebagai suami, sedang pihak wanitanya akan menjadi istri. Perbuatan hukum menyangkut harta bersama, misalnya menjaminkan atau menjual, baik dilakukan oleh salah satu pihak, suami atau istri, diperlukan adanya persetujuan pasanganya. $^{3}$

Persoalan harta benda dalam perkawinan sangat penting karena salah satu faktor yang cukup signifikan tentang bahagia dan sejahtera atau tidaknya kehidupan rumah tangga terletak pada harta benda. ${ }^{4}$ Sudah sangat jelas dan tegas, hukum menentukan bahwa harta yang diperoleh selama perkawinan menjadi harta bersama, dengan demikian sifat norma hukum yang melekat pada Pasal 35 Ayat (1) Undang-Undang Nomor 1 Tahun 1974 adalah memaksa (dwingenrecht) atau disebut juga imperative norma. ${ }^{5}$

Perjanjian pisah harta demikian menurut undang-undang diadakan setelah pernikahan dilangsungkan jika perjanjian dibuat sebelum perkawinan berlangsung adalah perjanjian perkawinan. Perjanjian mulai berlaku antara suami dan isteri, sejak mendapatkan ketetapan pengadilan di Pengadilan Negeri setempat dimana pasangan suami istrei berdomisili. Putusan Mahkamah Konstitusi Nomor 69/PUU- XIII/2015 memberikan peluang untuk diadakannya perjanjian kawin dalam ikatan perkawinan yang sebenarnya perjanjian perkawinan setelah pernikahan adalah perjanjian pisah harta. ${ }^{6}$

Seiring meningkatnya jumlah WNA yang bekerja dan menjalankan usahanya di Indonesia, mengakibatkan permintaan kebutuhan rumah tempat tinggal untuk WNA semakin meningkat apa lagi jika sudah terjadi perkawinan campur, hak warga negara Indonesia yang melakukan perkawinan campur harus dapat dilindungi dengan tidak mengesampingkan asas nasionalitas dari Undang-Undang Pokok Agraria. Peningkatan itu membuat pemerintah semakin perlu untuk memperjelas kepemilikan properti oleh

\footnotetext{
${ }^{1}$ Mardani. (2015). Kedudukan Hukum Islam Dalam Sistem Hukum Nasional, Jurnal Hukum, 2(16 April), 267-287

2 Adhitya Dimas Pratama, (2018), Kedudukan Kepemilikan Hak Atas Tanah Dalam Perkawinan Campuran Tanpa Adanya Perjanjian Pisah Harta, Jurnal Panorama Hukum, 3(2), 247-263

${ }^{3}$ Moch. Isnaeni, (2016), Hukum Perkawinan Indonesia, Bandung : PT Refika Aditama, h. 77

${ }^{4}$ Tan Kamello dan Syarifah Lisa Andrianti, (2015), Hukum Perdata : Hukum Orang \&

Keluarga, Medan : USU Press, h. 67

${ }^{5}$ Soebekti, R. (2001). Pokok-Pokok Hukum Perdata. Jakarta: Intermasa. h. 37

${ }^{6}$ Arief, H. (2015). Implementasi Yuridis Perjanjian Kawin dalam Sistem Hukum Positif di Indonesia. SYARIAH Jurnal Ilmu Hukum, 15(2), 141
} 
WNA sehingga pada akhir 2015 lalu dikeluarkanlah Peraturan Pemerintah Nomor 103 Tahun 2015 Tentang Pemilikan Rumah Tempat Tinggal Atau Hunian Oleh Orang Asing yang Berkedudukan di Indonesia (PP 103/2015). Peraturan Pemerintah tersebut lagi-lagi menyarankan untuk adanya perjanjian pisah harta bagi pelaku perkawinan campur agar WNI yang melakukan perkawinan campur tetap dapat memiliki hak Milik atas tanah namun tidak dengan pasangan WNA nya karena hartanya sudah milik masing-masing. Salah satu contoh Penetapan Pengadilan tentang pisah harta ini adalah Pengadilan Negeri Bekasi, yakni Penetapan Nomor 67/PDT.P/2014/PN.Bks.

\section{Metode Penelitian}

Jenis penelitian yang digunakan adalah penelitian hukum normatif yang meletakkan hukum sebagai sebuah bangunan sistem norma. Bahan hukum atau sumber hukum penelitian ini meliputi bahan hukum primer, sekunder dan tersier. Wawancara pada narasumber yang berkompeten dalam tema penelitian ini juga dilakukan peneliti guna mendapatkan gambaran dan kejelasan hukum terkait malasah-masalah yang dibahas. Penelitian ini dianalisis secara dreskriptif kualitatif dengan menggunakan metode deduktif yaitu data umum mengenai konsepsi hukum berupa asas-asas hukum, doktrin dan pendapat para ahli yang dirangkai secara sistematis sebagai susunan faktafakta hukum untuk mengkaji permasalahan pisah harta pada perkawinan campuran yang ada di Indonesia.

\section{Hasil Dan Pembahasan}

\section{A. Permasalahan dalam Perkawinan Campuran Tanpa Perjanjian Kawin}

Permasalahan pasangan perkawinan campuran sering muncul biasanya disebabkan ketidaktahuan atau kurang mengetahui tentang aturan dan tatacara perkawinan campuran beserta konsekuensinya, sehingga sangat dianjurkan calon pasangan perkawinan campuran untuk mengetahui aturan dan konsekuensinya sebelum melakukan perkawinan campuran. Aturan hukun dan tatacara perkawinan canpuran bisa diketahui dengan membaca literature tentang perkawinan campuran maupun dengan melakukan konsultasi ke instansi, lembaga, maupun orang yang berkompenten dan memahami perihal aturan hukum dan konskuensi dari perkawinan campuran. Ini penting dilakukan demi mengurangi permasalahan dikemudian hari setelah perkawinan campuran dilaksanakan.

Perkawinan campuran yang dilakukan di Indonesia dasar hukumnya adalah Pasal 59 ayat 1 Undang-Undang Nomor 1 Tahun 1974 tentang Perkawinan yang menyebutkan "bahwa perkawinan campuran tidak dapat dilaksanakan sebelum terbukti bahwa syaratsyarat perkawinan yang ditentukan oleh pihak masing-masing telah terpenuhi." Untuk membuktikan bahwa syarat-syarat tersebut telah dipenuhi dan karena itu tidak ada rintangan untuk melangsungkan perkawinan campuran maka oleh mereka yang menurut 
hukum yang berlaku bagi pihak masing-masing berwenang mencatat perkawinan, diberikan surat keterangan bahwa syarat-syarat perkawinan telah terpenuhi.

Jika ada pejabat yang berwenang menolak memberikan surat keterangan, maka atas permintaan yang berkepentingan bisa diajukan ke pengadilan. Pengadilan akan mengeluarkan penetapan pengadilan dengan tidak beracara serta tidak bisa mengajukan banding lagi tentang hal tersebut berasalan atau tidak yang berbentuk ketetapan, jika hasil pemeriksaan pengadilan menentukan bahwa penolakan tidak mempunyai alasan yang kuat maka ketetapan pengadilan tersebut menjadi pengganti keterangan syarat-syarat pernikahan. Masa dari Surat ketetapan pengadilan hanya berlaku selama enam bulan sesudah dikeluarkan. Jika perkawinan campuran itu dilakukan di luar negeri maka sesuai dengan Pasal 56 ayat 1 menyebutkan "perkawinan antara dua orang warganegara Indonesia atau seorang warganegara Indonesia dengan warga negara asing adalah sah bilamana dilakukan menurut hukum dinegara dimana perkawinan itu dilangsungkan dan bagi warganegara Indonesia tidak melanggar ketentuan Undang-Undang ini”.

Jika diawal saat ingin melakukan perkawinan campuran sudah dibenturkan dengan aturan hukum yang berlaku tidak dapat di hindarkan pula permasalahanpermasalahan yang datang setelah perkawinan campuran tersebut terjadi. Permasalahan yang mungkin terjadi biasanya tentang kewarganegaraan para pihak pelaku perkawinan campur, kewarganegaraan anak hasil perkawinan campur tidak jarang juga masalah harta benda keluarga tersebut. Khusus mengenai harta benda akan menarik karena di Indonesia jika cermat akan menemukan perjanjian yang dapat menjadi solusi terbaik serta tidak mengusik keharmonisan rumah tangga,serta bisa melindungi masing- masing pihak baik pihak isteri maupun pihak suami yaitu perjanjian pisah harta.

Mengapa bisa demikian, karena untuk tanah hukum pertanahan di Indonesia menganut asas nasionalisme (gronds verponding verbood) yang artinya melarang tanahtanah di Indonesia untuk dimiliki oleh orang yang bukan berkewarganegaraan Indonesia berdasarkan Pasal 21 ayat 3 Undang- Undang Nomor 5 tahun 1960 Tentang PokokPokok Agraria yang menyatakan bahwa dalam hal seseorang karena perkawinan, pewarisan, atau dengan cara lain kehilangan kewarganegaraan Indonesia, maka dalam kurun waktu satu tahun dia harus mengalihkan tanahnya kepada pihak ketiga atau tanah tersebut jatuh ke negara.

Kadang muncul pertanyaan untuk membuat kesepakatan pisah harta apakah pasangan suami istri harus menghadap notaris, inilah yang sering masyarakat pada umumnya salah kaprah dan beranggapan bahwa kalau sudah membuat kesepakatan pisah harta di depan notaris maka kesepakatan tersebut sudah sah dan mengikat dan menganggap sudah tidak ada lagi percampuran harta bersama. Padahal Mahkamah Agung Republik Indonesia dalam putusannya berpendirian bahwa Akta Pisah Pisah harta yang tidak dicatatkan pada Dinas kependudukan dan Catatan Sipil setempat adalah tidak sah dan tidak memiliki kekuatan hukum. Berdasar dari putusan Mahkamah Agung Republik Indonesia tersebut maka setelah pasangan suami istri membuat akta pisah harta harus 
segera dicatatkan ke Dinas Kependudukan dan Catatan sipil setempat agar akta pisah harta sah dan berkekuatan hukum.

\section{B. Dasar Hukum Pembuatan Kesepakatan Pisah Harta}

Kesepakatan pisah harta adalah bentuk perjanjian yang memuat tentang pernyataan bahwa semua harta pasangan suami istri yang di bawa sebelum mereka menikah, maupun pendapatan yang di peroleh setelah pernikahan dilakukan merupakan hak dan milik mereka sendiri, begitu pula dengan hutang dan piutang dari masing-masing pihak tersebut. ${ }^{7}$ Perjanjian ini sangat penting dibuat bagi para pelaku perkawinan campur yang tidak mengetahui dampak dari perkawinan campuran di Indonesia serta belum membuat perjanjian perkawinan meskipun sudah ada Putusan Mahkamah Konstitusi Nomor 69/PUU/XIII/2015. Mahkamah memberi tafsir konstitusional terhadap Pasal 29 ayat (1), ayat (3), dan ayat (4) tentang Perkawinan. Sehingga saat ini pembuatan perjanjian perkawinan bisa disesuaikan dengan kebutuhan hukum masing-masing pasangan, dalam perjanjian kawin dapat memuat pemisahan harta antara suami dan istri. ${ }^{8}$ Hal ini dikarenakan, dengan dibuatnya perjanjian pisah harta maka suami/ istri yang berkewarganegaraan Indonesia dapat tetap memiliki tanah di wilayah Indonesia dengan status hak milik ataupun hak guna bangunan serta saham di dalam perusahaan yang berstatus PT Indonesia.

Hal ini terjadi karena hukum di Indonesia menganut sistem percampuran harta, sebagaimana dimaksud dalam Pasal 35 Ayat (1) Undang-Undang Nomor 1 Tahun 1974 yang berbunyi "harta benda yang diperoleh selama perkawinan menjadi harta bersama". Perjanjian pisah harta ini hakekatnya tidak hanya di khususkan untuk pelaku perkawinan campuran saja melainkan bagi pasangan suami istri yang merasa harta kekayaannya terancam hilang akibat dari status pasangannya bisa membuat perjanjian pisah harta. Namun di Indonesia sangat lekat dengan adat ketimuran yang sering tidak merasa nyaman apalagi jika membicarakan masalah harta benda dalam keluarga apalagi bila perkawinan campuran itu terjadi dengan beberapa factor yang membuat salah satu pasangan merasa tidak berdaya mengajukan permohonan perjanjian pisah harta,maka dari itulah perjanjian ini tidak familiar di dengar oleh masyarakat pada umumnya, dan justru permasalahan harta ini terkadang memicu ketidakharmonisan bahkan bisa sampai tindak kekerasan dalam rumah tangga yang bisa berujung pada perceraian maupun tindak pidana.

Hanya sebagian pasangan saja yang telah membuat perjanjian pisah harta karena tingkat pemahaman serta kesadarannya akan pentingnya membuat perjanjian pisah harta. Untuk itu perlu sosialisasi dan pemahaman tentang adanya aturan hukum terkait perjanjian pisah harta ini.

\footnotetext{
${ }^{7}$ Addin Daniar Syamdan, D. P. (2019). Aspek Hukum Perkawinan Sirri Dan Akibat Hukumnya. Notarius, 12(1), 452-466.

${ }^{8}$ Rohman, M. F. (2017). Implikasi Putusan Mahkamah Konstitusi Nomor 69/PUU/XII/2015 tentang Perjanjian Perkawinan Terhadap Tujuan Perkawinan. Al-Daulah: Jurnal Hukum Dan Perundangan Islam, 7(1), 24.
} 
Penetapan Pengadilan mengenai Pemisahan harta sudah banyak terjadi di Indonesia yang juga merupakan dasar hukum dalam pengajuan pemisahan harta, beberapa contoh penetapan pengadilan pisah harta yang sudah ditetapkan di Indonesia antara lain sebagai berikut :

a. Penetapan Pengadilan Nomor 67/PDT.P/2014/PN.Bks,

b. Penentapan Pengadilan Nomor 16/Pdt.P/2016/PN.Tng,

c. Penetapan Pengadilan Nomor 1086/Pdt.P/2016/PN.Sby.

Mengenai ketentuan mengenai hak milik, sebagaimana telah diatur dalam Pasal 20-27 Undang-Undang Pokok Agraria, ketentuan mengenai hak milik dalam harta bersama (percampuran harta) akibat perkawinan campuran secara khusus diatur dalam Pasal 21 Undang-Undang Nomor 5 Tahun 1960 tentang Pokok-Pokok Agraria yang menyatakan bahwa :

a. "Hanya Warga Negara Indonesia yang dapat mempunyai hak milik;"

b. "Oleh pemerintah ditetapkan badan-badan hukum yang dapat mempunyai hak milik dan syarat-syaratnya;"

c. "Orang asing yang sesudah berlakunya Undang-Undang ini memperoleh hak milik karena pewarisan tanpa wasiat atau percampuran harta karena perkawinan, demikian pula warga negara Indonesia yang mempunyai hak milik dan setelah setelah berlakunya Undang-Undang ini kehilangan kewarganegaraanya wajib melepaskan hak itu didalam jangka waktu satu tahun sejak diperolehnya hak tersebut atau hilangnya kewarganegaraan itu. Jika sesudah jangka waktu tersebut terlampau hak milik itu tidak dilepaskan, maka hak tersebut hapus karena hukum dan tanahnya jatuh kepada negara, dengan ketentuan bahwa hak-hak pihak lain yang membebaninya tetap berlangsung."

d. "Selama orang disamping kewarganegaraan Indonesia mempunyai kewarganegaraan asing, maka ia tidak dapat mempunyai tanah dengan hak milik dan baginya berlaku ketentuan dalam ayat 3 Pasal ini."

Undang-Undang diatas mengatur, bahwa yang berhak atas tanah dengan hak milik adalah warga negara Indonesia. Namun faktanya WNI yang melakukan perkawinan campuran dengan warga negara asing (WNA) tanpa perjanjian perkawinan tidak berhak atas tanah dengan hak milik, dikarenakan terjadi percampuran harta dengan WNA.

Akan tetapi, mengenai hak milik WNI yang didasarkan pada Undang- Undang tersebut diatas, dirasa sudah sangat perlu mengalami perubahan. Menurut penulis Hak kepemilikan atas tanah melekat pada subyek pemiliknya. Kalau subyek adalah WNI, maka ia sah memiliki status Hak milik atas tanah. Sedangkan, pasangan WNA-nya sebagai subyek asing hanya berhak memiliki status hak pakai. 
Jadi yang tidak berhak atas tanah dengan status hak milik hanyalah warga negara asingnya baik karena pewarisan ataupun bercampurnya harta karena perkawinan serta WNI yang kehilangan kewarganegaraannya. Warga Negara Indonesia yang melakukan perkawinan campuran dengan Warga Negara Asing teteap menjadi warga negara Indonesia tunggal atau tidak ikuti kewarganegaraan pasangannya yang WNA selama hukum negara asal pasangannya tidak mengharuskan demikian.

Sedangkan Berdasarkan Undang-Undang Nomor 12 Tahun 2006 tentang Kewarganegaraan Republik Indonesia, bahwa "warga negara Indonesia yang melakukan perkawinan campuran dengan warga negara asing memiliki pilihan untuk melepaskan kewarganegaraannya Indonesia atau tetap menjadi Warga negara Indonesia."

Mengenai kepemilikikan tanah WNI dalam harta bersama akibat perkawinan campuran, sekalipun terjadi percampuran harta akibat perkawinan campuran dan kepemilikan atas harta apapun menjadi kepemilikan bersama, suami atau istri yang berstatus WNI seharusnya tetap berhak atas tanah dengan hak milik karena kedudukannya tetap sebagai WNI, lain perkara dengan pasangannya yang berstatus WNA hanya berhak atas tanah dengan status hak pakai. Kepemilikan atas tanah tersebut teteap kepemilikan bersama hanya status tanah tersebutlah yang berbeda, dikarenakan hak atas tanah tergantung pada pemegang haknya atau subyek pemiliknya. Hal ini sesuai dengan prinsip nasionalisme yang dianut oleh Undang-Undang Nomor 5 Tahun 1960 tentang Pokok Agraria.

Kendala yang akan dihadapi dalam kepemilikan rumah diatas tanah, sudah jelas Notaris-PPAT pasti akan mengatakan bahwa kalau terjadi perkawinan campuran (perkawinan antara WNI dengan WNA) tanpa perjanjian pisah harta tidak memungkinkan bagi mereka untuk kepemilikan rumah di atas tanah dengan status hak milik. Hal tersebut kembali dikarenakan oleh Pasal 21 ayat (3) Undang-undang Nomor 5 Tahun 1960 yang menyatakan bahwa WNA tidak berhak atas hak milik atas tanah. Akan tetapi, karena pembelian dilakukan oleh WNI Notaris-PPAT bisa menganjurkan begitu dibeli sebidang rumah diatas tanah tersebut. Maka status kepemilikannya diturunkan menjadi hak pakai karena kepemilikan rumah diatas sebidang tanah tersebut terjadi dalam harta bersama akibat perkawinan campuran yang tidak memiliki perjanjian pisah harta.

Apabila tidak ingin hal demikian terjadi (turunnya status hak milik menjadi hak pakai), biasanya Notaris itu akan memberikan solusi-solusi alternatif seperti untuk pinjam nama saudara atau kerabat dekat namun terkadang ada oknum yang biasanya mengakali aturan seperti membuat KTP single, Nominee Agreement atau yang lebih parahnya lagi melakukan perceraian terlebih dahulu dengan tujuan membuat perjanjian perkawinan kemudian menikah kembali. Tentunya hal tersebut sangat disayangkan karena menyimpangi aturan yang ada dengan cara membohongi aturan, bahkan yang lebih disayangkan lagi jika ada oknum notaris sebagai ahli hukum yang memberikan ide tersebut. Meskipun tidak semua Notaris sebagaimana dimaksud diatas ada pula yang menyarankan solusi terbaik saat ini yakni mengajukan penetapan pengadilan pisah harta. 
Penetapan pengadilan pisah harta adalah syarat untuk membuat perjanjian pisah harta yang memisahkan harta bersama dari suatu perkawinan. Namun tingkat kesadaran masyarakat Indonesia untuk membuat perjanjian perkawinan termasuk masalah pisah harta masih sangat rendah. Menurut UU Perkawinan perjanjian perkawinan tidak perlu dibuat dengan akta notaris,tapi pada kenyataannya kantor catatan sipil tidak menerima perjanjian perkawinan selain yang dibuat oleh notaris. Selain itu banyak terjadi pertentangan dalam hal persetujuan perkawinan yang dilakukan setelah pencatatan perkawinan dilaksanakan,sebagai contoh dalam hal perjanjian perkawinan dibuat diluar negeri namun perkawinan dicatatkan di Indonesia dalam kasus ini Kantor Catatan Sipil hanya akan menerima apabila sudah ada penetapan pengadilan yang berkekuatan hukum tetap. ${ }^{9}$ Lebih sulit lagi apabila persetujuan perkawinan dibuat di Indonesia akan tetapi perkawinannya dicatatkan di luar negeri dalam hal ini dipastikan kantor catatan sipil akan menolak mencatat perjanjian perkawinan tersebut sebagai bukti persetujuan perkawinan luar negeri.

Terlepas dari beberapa factor teknis yang agak rumit tetapi perjanjian perkawinan maupun Perjanjian pisah harta sangat penting dilakukan oleh suami istri dalam perkawinan campur hal ini untuk melindungi harta bawaan dari suami atau istri terhadap kemungkinan resiko yang bisa dialami suami atau istri , sebagai contoh kasus apabila akan mengajukan kredit ke bank maka suami atau istri bisa mengagunkan harta bawaan(bukan harta bersama) sebagai jaminan tanpa persetujuan pasangan(suami atau Istri) dan apabila ada resiko kredit macet maka yang akan disita adalah agunan yang diagunkan tersebut,tidak bisa menyita agunan harta bawaan dari pasangan.

Berbeda dengan harta bersama ,apabila suami atau istri mau mengagunkan sebagai jaminan ke bank maka perlu dilakukan perbuatan hokum bersama,biasanya kalau yang mengajukan suami maka pihak istri akan ikut serta tanda tangan persetujuan bahwa harta bersama tersebut akan dijadikan agunan,demikian pula sebaliknya apabila pihak isteri yang mengajukan maka pihak suami akan turut serta melakukan tindakan hukum atas harta bersama tersebut dengan melakukan tanda tangan persejuan bahwa harta bersama tersebut dijadikan sebagai jaminan,tentu pasangan suami istri tersebut dengan sadar mengetahui konsekuensi apabila ternyata dikemudian hari ada resiko atas perbuatan hokum terhadap harta bersama ini,misalnya terjadi kredit macet/wan prestasi maka harta bersama yang dijadikan agunan tersebut harus direlakan disita oleh pihak bank/kreditur. ${ }^{10}$ Berbeda apabila dalam mengambil tindakan hokum atas harta bersama tanpa ikut serta salah satu pasangan,tentu di samping pihak kreditur tidak akan berani juga sangat beresiko akan timbul gugatan dari salah satu pasangan yang merasa dilanggar haknya.

\footnotetext{
${ }^{9}$ Ade Nurhidayat, H. W., \& Kashadi. (2016). Analisis Yuridis Perkawinan Campuran Pria Warga Negara Asing (WNA) Menikah Dengan Wanita Warga Negara Indonesia (WNI) Menurut Undang- Undang No.1 Tahun 1974. Diponegoro Law Journal, 5(4), 1-12.

${ }^{10}$ Arief, H. (2017). Perjanjian Dalam Perkawinan (Sebuah Telaah Terhadap Hukum Positif di Indonesia). Al-Adl, 9(2), 151
} 
Selain hal diatas,dengan adanya perjanjian pisah harta ini pelaku perkawinan campur yang berstatus Warga Negara Indonesa bisa dengan mudah untuk melakukan pembelian sebidang tanah dengan status hak milik karena tanah yang dibeli tersebut bukan merupakan harta bersama sehingga tidak ada hak pasangannya yang Warga Negara Asing ( WNA) yang menjadi kendala status hak milik dalam penguasaan tanah mengacu kepada Undang- Undang tentang pertanahan/agraria. ${ }^{11}$

Tidak ada kendala terkait kepemilikan benda bergerak dalam hal ini kendaraan seperti mobil, sepeda motor, mesin-mesin produksi dan sejenisnya tidak dipermasalahkan kepemilikannya baik itu atas nama pasangan WNI ataupun atas nama pasangan WNA nya.

\section{Sengketa Hak Milik atas Tanah Karena Perkawinan Campuran}

Warga Negara Indonesia (WNI) yang melakukan perkawinan dengan Warga Negara Asing (WNA) tanpa membuat perjanjian perkawinan, memang tidak diperbolehkan untuk memiliki hak atas tanah yang berupa Hak Milik, Hak Guna Usaha ataupun Hak Guna Bangunan. Hal demikian sesuai dengan Pasal 35 UU Perkawinan yang menyatakan bahwa harta benda yang diperoleh selama perkawinan menjadi harta bersama. Jadi, ada percampuran harta yang diperoleh setelah perkawinan, dan pasangan (yang berstatus WNA) akan turut menjadi pemilik atas harta bersama tersebut.

Sedangkan merujuk pada ketentuan Undang-Undang Nomor 5 Tahun 1960 tentang Peraturan Dasar Pokok-Pokok Agraria, WNA tidak boleh memiliki Hak Milik, Hak Guna Usaha ataupun Hak Guna Bangunan. Karena itulah, seorang WNI yang menikah dengan WNA, setelah menikah tidak bisa lagi memperoleh Hak Milik, atau Hak Guna Bangunan, atau Hak Guna Usaha, karena akan menjadi bagian dari harta bersama yang dimilikinya dengan pasangan WNA-nya.

Prinsip nasionalitas dalam peraturan agraria di Indonesia tidak mengizinkan warga negara asing (WNA) memiliki tanah di Indonesia. Bahkan, warga negara Indonesia (WNI) yang telah melakukan perkawinan campuran dengan Warga Negara Asing (WNA ) tidak dapat mempunyai tanah dengan status hak milik atas tanah yang dibeli setelah melakukan perkawinan campuran, karena tanah tersebut dapat bercampur dan menjadi bagian dari harta bersama perkawinan. Lahirnya Peraturan Pemerintah No 103 Tahun 2015 semakin mempertegas dan menjadi solusi agar WNI dapat memiliki tanah dengan status hak milik ketika melakukan perkawinan campuran dengan WNA. Untuk mempertahankan prinsip nasionalitas agraria, Undang- undang No 5 Tahun 1960 Tentang Pokok-pokok Agraria (UUPA) menentukan bahwa hanya WNI yang dapat mempunyai hak milik atas tanah. Pasal 21 UUPA menegaskan bahwa WNA yang memperoleh hak milik karena pewarisan tanpa wasiat atau percampuran harta karena perkawinan sejak saat berlakunya UUPA tersebut wajib melepaskan hak milik atas tanahnya itu.

\footnotetext{
${ }^{11}$ Istrianty, A. (2015). Akibat Hukum Perjanjian Perkwinan Yang Dibuat Setelah Perkawinan Berlangsung. Privat Law, 3(2), 84-92.
} 
Begitu prinsipilnya asas nasionalitas ini, bahkan WNI yang juga memiliki kewarganegaraan lain di luar kewarganegaraan Indonesianya tidak dapat mempunyai tanah hak milik. Penguasaan properti oleh WNA hanya dapat dilakukan dengan hak pakai, demikian seperti ditentukan dalam Pasal 42 UUPA. Hak pakai merupakan hak untuk menggunakan dan/atau memungut hasil dari tanah yang dikuasai langsung oleh negara atau tanah milik orang lain. Hak pakai memberi wewenang dan kewajiban kepada WNA sebagaimana yang ditentukan dalam keputusan pemberiannya atau dalam perjanjian dengan pemilik tanah. Seiring meningkatnya jumlah WNA yang bekerja dan menjalankan usahanya di Indonesia, mengakibatkan permintaan kebutuhan rumah tempat tinggal untuk WNA semakin meningkat. Peningkatan itu membuat pemerintah semakin perlu untuk memperjelas kepemilikan properti oleh WNA sehingga pada akhir 2015 lalu dikeluarkanlah Peraturan Pemerintah Nomor 103 Tahun 2015 Tentang Pemilikan Rumah Tempat Tinggal Atau Hunian Oleh Orang Asing yang Berkedudukan di Indonesia (PP 103/2015). PP tersebut memberikan kepastian hukum dan kemudahan bagi orang asing untuk memperoleh rumah tempat tinggalnya di Indonesia, yang tentu saja dengan tetap memegang prinsip nasionalitas.

Berdasarkan Pasal 3 PP 103/2015, WNI yang melaksanakan perkawinan campuran dengan WNA masih dapat memiliki hak atas tanah yang sama dengan WNI lainnya yang tidak melakukan perkawinan campuran dengan WNA. WNI tersebut masih dapat memiliki hak milik atas tanah. Bahkan, namanya masih dapat tercantum dalam sertifikat hak milik (SHM) sebagai bukti kepemilikan. Syarat untuk tetap bisa memiliki hak atas tanah bagi WNI yang melakukan perkawinan campuran adalah hak atas tanah yang dimiliki WNI tersebut haruslah bukan harta bersama. WNI yang melakukan perkawinan campuran dengan WNA harus memisahkan hak atas tanah miliknya itu sehingga tidak masuk ke dalam harta bersama.

Untuk mengeluarkannya dari harta bersama, harus dibuktikan dengan Penetapan Pengadilan pemisahan harta antara suami dan istri, yang dibuat dengan penetapan pengadilan dimana pasangan perkawinan campuran tersebut berdomisili. Perjanjian pisah harta adalah perjanjian di antara suami-istri mengenai harta perkawinan mereka. Isi perjanjian itu terbatas hanya mengatur harta kekayaan dalam perkawinan dan tidak mengatur hal-hal lain di luar itu, misalnya tentang kekuasaan orang tua terhadap anak. Dalam Penetapan pengadilan pisah harta dapat ditentukan, suami dan istri dapat menguasai hartanya masing- masing dan memisahkannya dari harta bersama. ${ }^{12}$ Dengan pemisahan dari harta bersama itu, maka WNA pasangannya tidak turut memiliki tanahnya, sehingga WNI pasangan kawin campur bisa memperoleh tanah atau property dengan status hak milik. Yang paling penting, perjanjian pisah harta tersebut harus dibuat dengan ketetapan pengadilan terlebih dahulu karena syarat dari Pasal 186 KUHPerdata.

\footnotetext{
${ }^{12}$ Agustine, O. V. (2017). Politik Hukum Perjanjian Pasca Putusan Mahkamah Konstitusi Nomor 69/PUU-XIII/2015 Dalam Menciptakan Keharmonisan Perkawinan. Jurnal Rechts Vinding: Media Pembinaan Hukum Nasional, 6(1), 53.
} 
Menurut Pujiastuti selaku notaris di Kabupaten Bantul, WNI yang melakukan perkawinan campuran tanpa perjanjian perkawinan seharusnya tetap berhak atas tanah dengan status hak milik, selama ia tidak melepaskan kewarga negaraanya (tetap menjadi warga negara Indonesia). Walaupun terjadi kepemilikan bersama atas tanah dengan status hak milik dalam perkawinan campuran tanpa perjanjian perkawinan, seharusnya bisa dipisahkan status hak milik atas tanahnya. Warga negara Indonesia tetap berhak atas tanah dengan status hak milik, sedangkan pasangan warga negara asingnya hanya berhak atas tanah dengan status hak pakai.

Menurutnya juga menengai kepemilikan atas tanah dengan hak milik bagi WNI dalam harta bersama akibat perkawinan campuran masih dapat diusahakan namun dengan cara-cara yang illegal yang tentu sangat tidak terpuji bahkan bisa dikategorikan tindak pidana seperti dengan membuat KTP berstatus belum kawin atau kadang memanfaatkan perjanjian bawah tangan (nominee agreement) yang tentunya beresiko tinggi dan bisa berakibat hal yang merugikan bahkan tidak hanya bisa tersangkut persoalan hukum tetapi juga bisa berakibat kehilangan hak atas hartanya.

Dosen hukum Tata Negara Tanto Lailam menyayangkan "kebiasaan” buruk ini. Menurutnya "masalah yang nyata ditengah-tengah masyarakat ini seharusnya tidak ada lagi di era globalisasi. Seharusnya ada kebijakan, perhatian, insentif serta disentif mengenai pernikahan campuran meskipun sudah ada Peraturan Pemerintah Nomor 103 Tahun 2015 itupun hanya mengatur tentang kepemilikan hunian bagi WNA yang tinggal di Indonesia tidak menjawab semua permasalahan terkait perkawinan campur, harusnya khusus tentang akibat hukum apa saja yang akan timbul jika melakukan perkawinan campuran . Dibalik ini ada masalah yang lebih serius yaitu persoalan interkultural yang terkadang bisa menjadi persoalan tersendiri. Ini merupakan hal penting, kita perlu merinci apa saja yang mau disampaikan. Penyamaan persepsi diantara pelaku, yaitu NotarisPPAT, Bankir, Pejabat Pertanahan, dan tentunya Ahli hukum mungkin saja masih ada kesulitan karena tidak tertulis dengan jelas di Undang-Undang maupun adanya perbedaan pendapat atau penafsiran atas aturan tentang perkawinan campuran." Solusi terbaik saat ini yang juga merupakan dasar hukum yang kuat agar dapat digunakan sebagai landasan kepemilikan tanah dengan status hak milik dan tentunya legal yakni penetapan pengadilan pisah harta.

Penetapan pengadilan pisah harta adalah penetapan pengadilan tentang pemisahan harta bersama suami isteri setelah dikabulkanya permohonan pisah harta atau dikeluarkannya penetapan pengadilan ini. ${ }^{13}$ Yang tadinya dalam perkawinan campuran tersebut terjadi percampuran harta (harta bersama) setelah berlakunya penetapan ini menjadi terpisah. Sehingga apa yang dihasilkan oleh suami setelah penetapan ini adalah hanya menjadi milik suami dan begitu pula isteri, apa yang dihasilkan oleh isteri adalah hanya menjadi milik isteri seutuhnya. Namun suami yang berkewarganegaraan asing

\footnotetext{
${ }^{13}$ Aryani, N. M. (2018). Implikasi Putusan Mhkamah Konstitusi Nomor 69/PUU-XIII/2015 Pada Pembuatan Perjanjian Perkawinan. Vyavahara Duta, 13(2), 26-27.
} 
sebagai kepala keluarga akan dan harus tetap bertanggung jawab sepenuhnya untuk biaya hidup keluarga dan juga pendidikan anak anak yang telah dan akan dilahirkan oleh isterinya yang berkewarganegaraan Indonesia.

\section{Simpulan}

Dasar hukum pembuatan pemisahan pisah harta pada perkawinan campuran tanpa perjanjian perkawinan di indonesia adalah Putusan Mahkamah Konstitusi Nomor 69/PUU/XIII/2015, Mahkamah memberi tafsir konstitusional terhadap Pasal 29 ayat (1), ayat (3), dan ayat (4) tentang Undang-Undang Perkawinan. Kini, pembuatan perjanjian perkawinan bisa disesuaikan dengan kebutuhan hukum masing-masing pasangan serta Adanya Yurisprudensi dari penetapan sebelumnya. Penyelesaian sengketa hak milik atas tanah pada perkawinan campuran tanpa perjanjian kawin di indonesia dengan mengajukan permohonan pisah harta oleh salah satu pasangan suami-isteri ke pengadilan sesuai kopetensi relatifnya. Penyelesaian ini menurut peneliti adalah satu-satunya cara yang terbaik dan legal dimata Hukum.

\section{Daftar Pustaka}

\section{Buku}

Isnaeni, M. ( 2016). Hukum Perkawinan Indonesia. Bandung : PT Refika Aditama.

Mukti Fajar ND, Y. A. ( 2015). Dualisme Penelitian Hukum. Yogyakarta: Pustaka Pelajar.

Soebekti, R. (2001). Pokok-Pokok Hukum Perdata. Jakarta: Intermasa.

Tan Kamello, S. L. ( 2015). Hukum Perdata : Hukum Orang \& Keluarga. Medan: USU Press.

\section{Jurnal}

Agustine, O. V. (2017). Politik Hukum Perjanjian Pasca Putusan Mahkamah Konstitusi Nomor 69/PUU-XIII/2015 Dalam Menciptakan Keharmonisan Perkawinan. Jurnal Rechts Vinding: Media Pembinaan Hukum Nasional,6(1), 53-67.

Arief, H. (2015). Implementasi Yuridis Perjanjian Kawin dalam Sistem Hukum Positif di Indonesia. SYARIAH Jurnal Ilmu Hukum, 15(2), 141-154.

Arief, H. (2017). Perjanjian dalam Perkawinan (sebuah Telaah terhadap Hukum Positif di Indonesia). Al-Adl, 9(2), 151-172, doi:10.31602/al-adl.v9i2.935.

Aryani, N. M. (2018). Implikasi Putusan Mahkamah Konstitusi Nomor 69/PUUXIII/2015 Pada Pembuatan Perjanjian Perkawinan. Vyavahara Duta, 13(2), 6371. 
Istrianty, A. \& Priambodo, I. (2015). Akibat Hukum Perjanjian Perkwinan yang dibuat Setelah Perkawinan Berlangsung. Privat Law, 3(2), 84-92.

Mardani. (2015). Kedudukan Hukum Islam Dalam Sistem Hukum Nasional. Jurnal Hukum, 2(16 April), 267-287.

Nurhidayat, A., Widanarti, H., \& Kashadi. (2016). Analisis Yuridis Perkawinan Campuran Pria Warga Negara Asing (WNA) Menikah dengan Wanita Warga Negara Indonesia (WNI) menurut Undang - Undang No 1 Tahun 1974. Diponegoro Law Journal, 5(4), 1-12. Retrieved from https://ejournal3.undip.ac.id/index.php/dlr/article/view/13763

Pratama, A. D. (2018). Kedudukan Kepemilikan Hak Atas Tanah Dalam Perkawinan Campuran Tanpa Adanya Perjanjian Pisah Harta. Jurnal Panorama Hukum, 3(2), 247-263. https://doi.org/10.21067/jph.v3i2.2828.

Rohman, M. F. (2017). Implikasi Putusan Mahkamah Konstitusi Nomor 69/PUU/XIII/2015 Tentang Perjanjian Perkawinan Terhadap Tujuan Perkawinan. Al-Daulah: Jurnal Hukum Dan Perundangan Islam, 7(1), 1-27. https://doi.org/10.15642/ad.2017.7.1.1-27.

Syamdan, A. D., \& Djumadi Purwoatmodjo, D. (2019). Aspek Hukum Perkawinan Siri dan Akibat Hukumnya. Notarius, 12(1), 452-466. https://doi.org/10.14710/nts.v12i1.28897 